\title{
COMMUNITY EMPOWERMENT MODEL FOR TOBACCO FARMERS IN LENGKONG DISTRICT OF NGANJUK REGENCY, INDONESIA
}

\author{
Munir M.*, Student \\ Doctoral Study Program of Environmental Sciences, Brawijaya University, Indonesia
}

Fanani Z., Soemarno, Leksono A.S.

Lecturers of Brawijaya University, Indonesia

*E-mail: nichepermata@gmail.com

\begin{abstract}
This study aims to analyze the potential of the tobacco field in Lengkong District Nganjuk Regency; Analyzing factors related to the empowerment of Tobacco Farmers in Lengkong District in Nganjuk Regency; Find a model of community empowerment for Tobacco Farmers in the Lengkong District in Nganjuk District. This research was conducted on $10^{\text {th }}$ of June 2019 to $11^{\text {th }}$ of March 2020 in Lengkong District, Nganjuk Regency. The types of research are case study and explanatory research. The results showed that the location of the potential research in the field of tobacco was seen from the characteristics of farmers consisting of age, education level, farming experience, family participation, and land ownership. Factors that related to farmer empowerment consist of human resources, natural availability, financial availability, physical capital, and social capital, while in the community empowerment model of tobacco farmers in the district of Bengkong in Nganjuk Regency the results use the Parameter Estimation Model with hypothesis testing.
\end{abstract}

\section{KEY WORDS}

Tobacco potentials, empowerment models, tobacco farmers.

Empowerment is a process of developing, independence, self-empowerment, strengthening the bargaining position of the lower classes of society against the forces of pressure in all fields and sectors of life (Eko, 2002). The concept of empowerment (village community) can also be understood with two perspectives. First, empowerment is interpreted in the context of placing community standing. The position of the community is not objects (beneficiaries) that depend on gifts from outside parties such as the government, but in the position as subjects (agents or participants who act) who act independently. Acting independently does not mean being free from state responsibility. Providing public services (health education, housing, transportation and so on) to the public is certainly a given task (obligation) of the state. Independent community as a participant means opening up space and capacity to develop creative potential, control the environment and its own resources, solve problems independently, and participate in determining the political process in the realm of the state. The community participates in the development process and governance (Eko, 2002). Permendagri RI (Domestic Government Regulations) No. 7 of 2007 about Cadres of Community Empowerment, stated that community empowerment is a strategy that used in community development as an effort to realize the ability and independence in the life of society, nation and state (Article 1, paragraph (8)). The core understanding of community empowerment is a strategy to realize the ability and independence of the community.

Some of the problems in empowering rural communities from an economic aspect include; lack of economic institutional system development to provide opportunities in developing competitive economic business activities; the lack of creating community access to economic resource inputs in the form of capital, business location, business land, market information, and production technology, and the weak ability of the community to build 
community economic organizations that can increase their bargaining potential and competitiveness so as to have economic independence (Septiani et al, 2010).

Agricultural development is an integral part of economic development and general community development. Agricultural development is a product of the community and contributes to it and ensures that overall development will be truly general, and includes large numbers of people who live from farming, and for many years to come in various countries, it will continue living from farming.

Tobacco commodities in Indonesia must be preserved because they have specific taste, fragrance and texture specifications and are the main raw material for the clove cigarette industry in Indonesia. Thus as a regional superior product, Temanggung tobacco has a high economic value and is a culture of Indonesian society that has been implemented in a descending manner.

Therefore, as many as 20 million people depend on the tobacco products industry (Soemiran, 2008) Indonesian cigarette production each year an average of 210 billion sticks, consisting of $89 \%$ clove cigarettes and $11 \%$ white cigarettes. During the monetary crisis, the kretek cigarette industry was not affected because $86 \%$ of the tobacco raw materials came from within the country and only a small portion came from imports.

The objectives of this study are: (a) Analyzing the potential of the tobacco field in Lengkong District, Nganjuk Regency; (b) Analyzing the factors that involved in the empowerment of Tobacco Farmers in Lengkong District in Nganjuk Regency; (c) Finding a model of community empowerment for Tobacco Farmers in the Lengkong District in Nganjuk District

\section{METHODS OF RESEARCH}

There are two types of research used in this study, namely case study and explanatory research. The research was conducted by survey method. Based on the purpose of this study, the determination of the sample and location of the study was done purposively. The place of this research is the Tobacco Farmers in the lengkong village, Nganjuk, with the object of all staff employees and elements of leadership and village administrators and the capital of the lengkong district, Nganjuk. This research was conducted within a period of 10 months, which is calculated from $10^{\text {th }}$ of June 2019 to $11^{\text {th }}$ of March 2020.

\section{RESULT OF STUDY}

Potential of Tobacco Sector in Lengkong District, Nganjuk Regency. Based on the results of the study, it showed that the majority of tobacco farmers are between 19-68 years old $(89.7 \%)$ this age showed a productive workforce or still in an active level of work. Farmer education level is mostly in junior high school education (45.45\%) respondent education level is a description of the ability or quality of farmers' resources formally that is closely related to the ability of a farmer to absorb information in the form of knowledge and technology that will direct farmers to develop their business. The higher the level of education of farmers, the knowledge and mastery of technology in developing the Tobacco business will be higher, so that it can increase productivity and income by utilizing more efficient resources and tobacco farming can be sustainable. In the experience of farming the majority of respondents have been farming between 12-19 years old (43.64\%). Based on the experience and capabilities of the Farmer, of course the desire to be able to increase production yields as well as income from tobacco business activities is very large, but they still need the help of agricultural extension workers to help in adding their insights, especially in managing their tobacco businesses. Based on the number of family members, the help of wife and children in the tobacco business is less visible, because only $44.24 \%$ of the wives are helping, and even only $24.2 \%$ of respondents are assisted by their children in farming. Respondents in this study mostly have tobacco plantations between 1-5 plots / ha (86.06\%). 


\section{Factors that Related to Empowering Tobacco Farmers:}

- Human resources. Farmer knowledge is in the good category; it means farmers have sufficient knowledge to run a tobacco business. However, the skills needed need to be improved again. In tobacco farming businesses can absorb labor to carry out these businesses with the help of family members;

- Nature Availability. The weather / climate in the Bengkong Subdistrict in Nganjuk Regency are quite supportive in the tobacco business. In the other hand, the environmental cleanliness, land availability, and quantity of waste are in the quite well category in supporting the business;

- Financial availability. This tobacco business provides sufficient benefits for farmers in terms of marketing, commodity competitiveness, availability of tobacco product management industries, and the existence of micro finance institutions;

- Physical capital. The availability of roads access, the availability of facilities and infrastructure, marketing access, and the availability of business houses are quite well available to support tobacco farming;

- Social capital. Social capital owned by farmers is utilizing technology in the application of agricultural business, support from surrounding communities; there is the role of extension institutions, and the formation of farmer groups.

The Community Empowerment Model of Tobacco Farmers in Lengkong District, Nganjuk Regency. The Model of Community Empowerment of Tobacco Farmers in Lengkong District in Nganjuk District results using the Model Parameter Estimation by testing the hypothesis; Human Resources (X1) are measured by five indicators such as Farming Knowledge (X1.1), Farmer Skills (X1.2), Farming Experience (X1.3), Absorption of Tobacco Business Workforce (X1.4) and Family Participation in Tobacco Business (X1.5) do not have a significant influence on Tobacco Business Sustainability $(Y)$ with a coefficient of -0.033 and $\mathrm{p}$-value of 0.783 . This means that the high or low value of human resources (X1), will not result in a high or low value of Tobacco Business Sustainability $(Y)$.

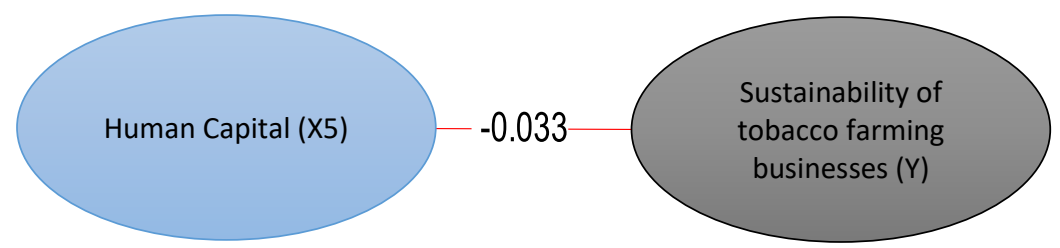

This shows that human resources (X1) in this study are aspects that cause the sustainability of tobacco business is only quite sustainable $(67.88 \%)$, in general, farming knowledge and skills regarding the ins and outs of tobacco business from the business side do not experience problems, they really understand how to properly raise cows. They claim to have acquired knowledge handed down from generation to generation by their families. However, this is not enough as capital in running a Tobacco business to be more sustainable (growing). Lack of entrepreneurial initiative in making innovations or new breakthroughs related to the development of the Tobacco business is still frequently encountered, such as the lack of the social media use or the lack of Tobacco entrepreneur response to the market. This is allegedly due to the influence of the educational background which in turn is difficult to accept the changes that occur in the community so that it has negative implications for the development of tobacco business in the future. So the effort to improve human resources (X1) is to strive for better farmers' knowledge and skills.

Human resources can be conceptualized as a function of individuals who provide value to organizations, such as resources that provide tools for organizations to create value (Reed et al, 2009). Human resources have been believed to be one of the distinguishing resources of company performance in company studies (Hitt et al, 2001). Human resource management requires attention to two things: the provision of knowledge and the flow of knowledge. Human resources are providing the ability for companies to respond flexibly to environmental changes. In the Tobacco business, human resources will have an impact on 
Tobacco Business Sustainability $(Y)$ as measured by the Increase in Tobacco Selling Prices (Y.1) and Increased Tobacco Farmer Production (Y.2). Therefore, it can be said that increasing capacity and capability of human resources will improve company performance (Reed et al, 2009). The implication of improving human resources (X1) is the Sustainability of Tobacco Enterprises (Y).

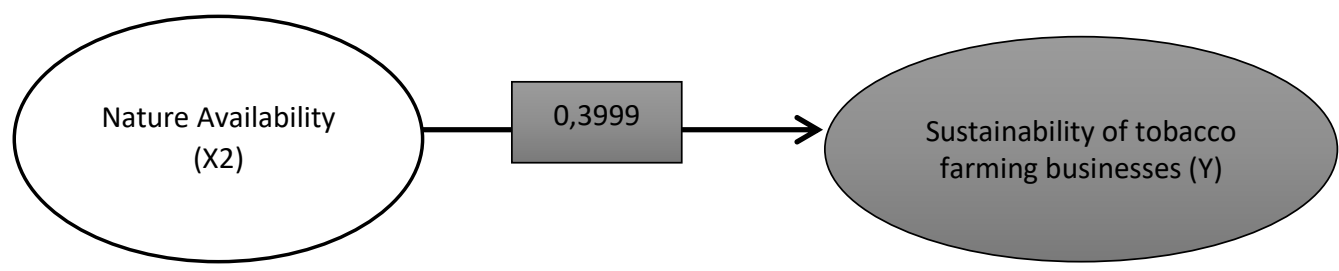

Based on the results of the analysis, the coefficient of the relationship between the availability of nature (X2) with the Tobacco Business Sustainability $(Y)$ is equal to 0.399 with a $p$-value of 0.006 . A $p$-value $<0.05$ indicates that the availability of nature (X2) has a significant effect on Tobacco Business Sustainability $(Y)$. Positive coefficients indicate directional relationships. This means that the higher the value of natural availability (X2), will result the higher value of Tobacco Business Sustainability $(Y)$.

Based on the analysis of the nature availability (X2) which is measured by five indicators such as Weather Suitability (X2.1), Environmental Cleanliness of tobacco businesses (X2.2), Land Suitability (X2.3), Land Availability for HPT (X2.4 ) and the Agriculture Waste Quantity (X2.5), it is known that the strongest indicator as a gauge is the Environmental indicators of tobacco business (X2.2) with a loading value of 0.675 and an average indicator of 3.44 which is the highest average compared to the average other indicators. Based on the average value, the indicator of Environmental Cleanliness of tobacco business (X2.2) has been assessed well by respondents so that it can be said that the high variable availability of nature (X2) is mainly due to the indicator of Environmental Cleanliness of tobacco business (X2.2).

From the five indicators that measure the natural availability variable, it is known that the Agriculture Waste Quantity indicator (X2.5) is the lowest indicator with a loading value of 0.424 and an average indicator of 3.29 which is considered quite good by respondents. Thus it can be said that to strengthen the availability of nature (X2) improvements should be made to the indicator of Agricultural Waste Quantity (X2.5).

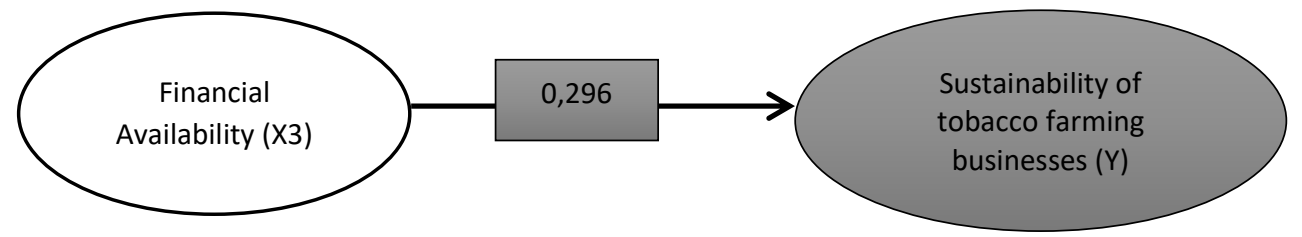

Based on the results of the analysis, the coefficient of the relationship between financial availability (X3) with Tobacco Business Sustainability $(Y)$ is 0.296 with a p-value of 0.014 . A p-value $<0.05$ indicates that financial availability $(X 3)$ has a significant effect on Tobacco Business Sustainability (Y). The coefficient marked positive indicates a direct relationship. This means that the higher the value of financial availability $(\mathrm{X} 3)$, will affect the higher the value of Tobacco Business Sustainability $(Y)$.

From the results of the analysis of the actors in financial availability (X3) measured by five indicators such as Tobacco Business Profit (X3.1), Marketing of tobacco products (X3.2), Competitiveness of commodities (X3.3), Availability of the tobacco product management industry (X3 .4) and the existence of a microfinance institution (X3.5), shows that the existence of a microfinance institution (X3.5) is an indicator with the highest loading value of 0.682 with an average indicator of 3.41 where in this case the indicator of the existence of a microfinance institution (X3.5) has been rated well by respondents. Based on this it can be said that financial availability (X3) is high mainly due to the high existence of microfinance 
institutions (X3.5). While the lowest indicator is the commodity competitiveness indicator (X3.3) with a loading value of 0.500 and an average indicator of 3.40. Although the commodity competitiveness indicator (X3.3) is considered quite well by respondents, however, the commodity competitiveness indicator (X3.3) still needs to be improved. So the effort to improve financial availability (X3) is to strive for better commodity competitiveness (X3.3).

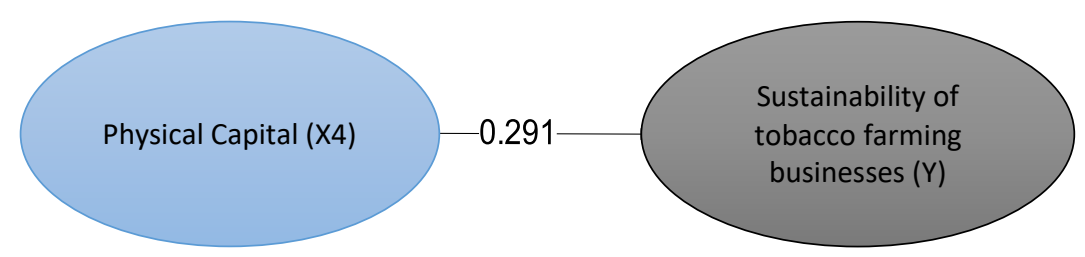

Based on the results of the analysis, the coefficient of the relationship between Physical Capital (X4) is measured by five indicators, namely the availability of road access for tobacco businesses (X4.1), Availability of Facilities and infrastructure of tobacco business (X4.2), Public Access to Tobacco Marketing (X4. 3), Community Access in Farming activities (X4.4) and Availability of Tobacco Business Development House (X4.5) with Tobacco Business Sustainability $(Y)$ is 0.291 with a $p$-value of 0.021 . The $p$-value $<0.05$ indicates that Physical Capital (X4) has a significant effect on Tobacco Business Sustainability (Y). Positive coefficients indicate a direct relationship. This means that the higher the value of Physical Capital (X4), the higher the value of Tobacco Business Sustainability (Y).

If it is seen from the results of the analysis of the actors in Physical Capital (X4) it is known that the strongest indicator as a gauge is the Community Access indicator in Farming activities (X4.4) with a loading value of 0.683 and an average indicator of 3.38. Although it is not the highest average compared to the average of other indicators, the Community Access indicator in Farming activities (X4.4) has been considered quite good by respondents. Based on this it can be said that the high physical capital variable (X4) is mainly due to the Community Access indicators in Farming activities (X4.4).

From the five indicators that measure the physical capital variable, it is known that the Availability of road access indicators for tobacco business (X4.1) is the lowest indicator with a loading value of 0.510 and an average indicator of 3.52 which is rated well by respondents. Thus it can be said that to strengthen physical capital (X4) improvements should be made to the indicator of the availability of road access for tobacco businesses (X4.1).

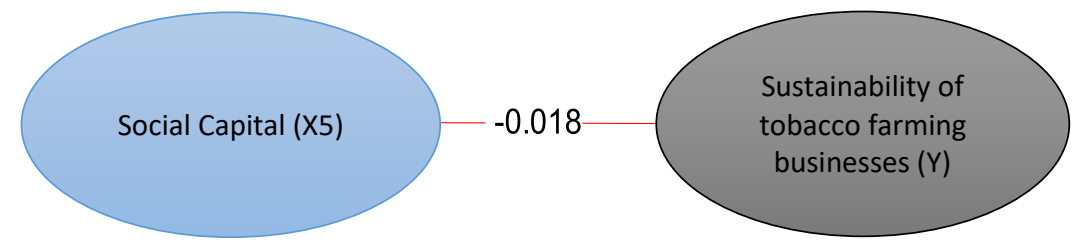

Based on the analysis, the correlation coefficient between Social Capital (X5) and Tobacco Business Sustainability $(Y)$ is -0.018 with a $p$-value of 0.876 . A p-value $>0.05$ indicates that Social Capital (X5) has no significant effect on Tobacco Business Sustainability $(Y)$. This means that the high or low value of Social Capital (X5), will not result in a high or low value of Tobacco Business Sustainability $(Y)$.

This shows that Social Capital (X5) in this study is an aspect that causes the sustainability of tobacco business is only quite sustainable $(67.88 \%)$. In general, the level of mastery and application of technology (X5.1), community views on tobacco business (X5.2), community empowerment in agricultural activities (X5.3), the existence and role of extension institutions (X5.4), and group presence farmers (X5.5) lack of support for the sustainability of the Tobacco business. Community Empowerment in Agriculture activities (X5.3) is an indicator with the highest loading value of 0.730 with an average indicator of 3.33 . The lowest indicator is the level of technology mastery and application (X5.1) with a loading value of 
0.452 and an average indicator of 3.48. So the effort to improve Social Capital (X5) is to strive for a better level of mastery and application of Technology (X5.1).

The company's value is now more determined by intangible assets. The ability to identify and assess the sources of these assets is a critical aspect that needs attention from the company (Zuhdi et al, 2015). Social capital is one of the types of resources included in invisible assets.

In the literature, social capital can consist of knowledge, expertise, skills, experience, competence, creativity, cooperative ability, loyalty, problem-solving ability, attitude and motivation (Hsu \& Fang, 2009). Social capital can be interpreted as one individual's relationship with individuals, organizations and the environment (Reed et al, 2009).

Social capital is one form of capital in the classification of types of capital by the world bank which is recognized as the most important type of capital. Social capital has a special role in the knowledge-based economy. According to Zuhdi et al (2015) one of the company's significant capabilities in empowering organizations to create and share knowledge and provide sustainable organizational excellence is social capital.

The concept of social capital originally came from the sociology science, the latest developments revealed an increased interest in research on social capital from other fields of science. The reason that drives it is the existence of social capital will facilitate mutually beneficial coordination and cooperation, and finally, the creation of value (Pinho and Soares 2011).

Social capital is an indispensable and crucial component in developing business organizations. Social capital will lead to increased social cohesion, teamwork, communication intensity, reducing the possibility of opportunistic behavior and the costs of supervision, encouraging cooperative behavior and innovation in organizations, creating new opportunities and resolving disputes. In a complex business environment with intense competition, an increase in social capital is an important element to ensure an organization's survival and competitive advantage.

Humans play a key role in company productivity. Therefore, changes in the business environment must be addressed by companies by means of a new human resource management approach. The aim is to survive and create business sustainability (Nguyen \& Nguyen, 2012).

According to Pinho (2013) physical capital (finance) and human resources can lead to productivity, with the existence of social capital, productivity can be multiplied. This opinion was also strengthened by Farahani (2008) who conducted research on the role of social capital in the work environment and productivity. The conclusion is that social capital is a source of productivity in business organizations. Employees who have a work environment with higher social capital will produce higher performance than other companies whose assets are larger.

Social capital plays a role in the utilization of physical capital and human resources. Its absence will cause the utilization of other types of capital to be less optimal and less effective (Zuhdi et al, 2015). Human resources are functions of individual processes, while social capital is functions of individual learning processes in organizations (didactic). Both of these capitals have been explicitly identified as resources that can be directly linked to company performance (Reed et al, 2009). So to improve the sustainability of the Tobacco business it is necessary to improve social capital in a positive direction.

\section{CONCLUSION}

Potential Tobacco Sector in Lengkong District Nganjuk Regency, the area of land reaches 49.88 ha only for tobacco plants. Judging from the Characteristics of Farmers Respondents Potential In the form of the age of farmers mostly included in the productive age, the level of education of farmers are mostly in junior high school education, the majority of respondents have been farming from 12-19 years old, Family Members involved in tobacco business, Respondents in this study mostly had tobacco plantations between 1-5 plots / ha, and the majority of farmers who own rice fields and tobacco plantations. 
Factors that related to Empowering Tobacco Farmers are declared valid and reliable in the form of human resources, natural availability, financial availability, physical capital, social capital, and tobacco business sustainability.

The Model of Community Empowerment of Tobacco Farmers in Lengkong District in Nganjuk Regency, using the Estimated Model Parameters, such as; First, the high or low value of human resources, will not result in a high or low value of Tobacco Business Sustainability; second, the higher the value of natural Availability, the higher the value of Tobacco Business Sustainability will occur; Third, the higher the value of financial availability, will affect the higher the value of Tobacco Business Sustainability; fourth, the higher the value of Physical Capital (X4), the higher the value of Tobacco Business Sustainability; Fifth, the high or low value of Social Capital (X5), will not result in a high or low value of Tobacco Business Sustainability.

For local governments, it is recommended in the preparation of tobacco farmer development, prioritizing the improvement of infrastructure to assist farmers in running their tobacco businesses. Physical capital related to the provision of infrastructure is very much needed by farmers. The availability of access roads for livestock businesses is very much needed by farmers, in addition to the availability of tobacco business facilities and infrastructure. The government is also needed to help farmers in marketing and the availability of tobacco business development houses.

\section{REFERENCES}

1. Eko, S. 2002. Pemberdayaan Masyarakat Desa, Materi Diklat Pemberdayaan Masyarakat Desa. Samarinda.

2. Farahani, "Zigbee Wireless Network and Tranceiver," in Zigbee, Newyes: Burlington, 2008, p. 5.

3. Hitt, Michael A. et al., 2001. Manajemen Strategis: Daya Saing and Globalisasi; Konsep Buku 1. Jakarta: Salemba Empat.

4. Hsu, Y.H. and Fang, W., (2009). Intellectual capital and new product development performance: The mediating role of organizational learning capability. Technological Forecasting and Social Change, 76(5), pp.664-677.

5. Nguyen Thanh and Nguyen Thi. (2012). The Effect of Capital Structure on Firm Value for Vietnam's Seafood Processing enterprises. International research Journal of Finance and Economics - Issue 89. Eurojournals Publishing, Inc.

6. Permendagri RI No.7 tahun 2007 tentang Kader Pemberdayaan Masyarakat.

7. Pinho, J., \& Soares, A. M. (2011). Examining the Technology Acceptance Model in the Adoption of Social Networks. Journal of Research in Interactive Marketing, Vol 5(2/3), 116-129.

8. Reed, S.M., G raves, A., Dandy, N., Posthumus, H., Huback, K., Morris, J., \&, Stringer, L.C. (2009). Who's in and why? A typology of stakeholder analysis methods for natural re-sources management. Journal of Environmental Management, 90, 1933-1949.

9. Septiani, M., Soemarno, Purwadio. 2010. Community Participation Improvement on mpowerment National Program of Urban Autonomous Communities, Case Study: Tlogomas Sub-district, Lowokwaru District Malang. Seminar Nasional Perumahan, Pemukiman dalam Pembangunan Kota.

10. Soemiran, I. 2008. KRETEK: Today and Tomorrow. The 12th National Tobacco Association Conference. Gappri-Gaprindo. Denpasar, Bali.

11. Subramaniam, M., \& Youndt, M. A. (2005). The influence of intellectual capital on the types of innovative capabilities. Academy of Management Journal Vol. 48, 450-463.

12. Zuhdi, Firdaus Aprian, et al. 2015. Pengaruh Penerapan E-SPT and Pengetahuan Perpajakan Terhadap Kepatuhan Wajib Pajak (Studi Pada Pengusaha Kena Pajak yang terdaftar di KPP Pratama Singosari). Jurnal Perpajakan (JEJAK); Vol. 7 No.1. 